\title{
Yiddish metal as a manifestation of postvernacularity
}

Lily Kahn, University College London

Running head: Yiddish metal as a manifestation of postvernacularity

\begin{abstract}
This chapter investigates Yiddish-language heavy metal music as a manifestation of postvernacularity. Yiddish, the traditional language of Ashkenazic Jews, is now endangered with a geographically dispersed speaker base and a low rate of transmission to younger generations outside of strictly Orthodox communities. However, as the heritage language of most Ashkenazic Jews, Yiddish continues to play an important symbolic role in contemporary Jewish life even among those who do not speak or understand it. This phenomenon has been termed 'postvernacularity' (Shandler, 2006).

Yiddish is associated with a rich tradition of folk songs, popular songs, and ballads. Recent decades have seen a growing interest among younger generations in Yiddish language and culture, including its musical tradition. In addition to musicians specialising in traditional Yiddish song, there are also currently two bands worldwide who have produced a metal album in Yiddish: Gevolt (Israel) and Dibbukim (Sweden). The repertoire of both bands is comprised largely of classic Yiddish songs interpreted in a metal style but retaining the traditional lyrics and melodies.

The fact that these metal bands often choose to reinterpret traditional staples rather than composing original Yiddish songs can be seen as a reflection of the predominantly postvernacular status of Yiddish. The language plays an iconic role for band members and audiences. Concurrently, the fusion of familiar Yiddish songs with metal style makes a language often associated with traditional Ashkenazic society relevant to the 21 st-century.
\end{abstract}

\section{Keywords}

Yiddish, Jewish, postvernacular, heavy metal, klezmer, folksongs

\section{Introduction}

This chapter investigates Yiddish-language heavy metal music as a manifestation of postvernacularity. Yiddish is the traditional language of Ashkenazic (Central and East European) Jewry. It likely emerged sometime around 1,000 CE in the Germanic-speaking regions of Central Europe, either the Rhineland or Bavaria (see Kahn, 2016). Yiddish is a 
Germanic language with significant Semitic and Slavic lexical and grammatical components. It was the main language of Eastern European Jews until the mid-20th century, with approximately 11-12 million speakers worldwide on the eve of World War II.

Yiddish had an established literary tradition which first emerged in the medieval period. Beginning in the 19th century, it developed into a modern literary language, and by the interwar period it was the vehicle of a flourishing press, original and translated fiction, a vibrant theatrical scene, and a popular film industry (see Kahn, 2016). This flourishing Yiddish-speaking cultural activity was cut short by the Holocaust, which decimated the Eastern European Jewish population. Combined with other major historical factors such as mass emigration from Eastern Europe, which had started in the late 19th century and led to widespread linguistic assimilation among subsequent generations, Stalinist repression of Yiddish in the Soviet Union from the late 1930s onwards, and the establishment of Hebrew as the vernacular in Ottoman and Mandate Palestine and later the State of Israel, Yiddish language and culture suffered a severe decline from the mid-20th century onwards (Harshav, 1990, pp. 84-8). As a result, in the 21st century it is classified by UNESCO as a 'definitely endangered' language. Its speakers are dispersed internationally, it has no official national status anywhere in the world, and it benefits from very little to no state support or infrastructure.

Estimates of current Yiddish speaker numbers vary widely, from anywhere between half a million and two million, with difficulties including lack of consistent census data for the geographically discrete communities and uncertainty regarding levels of fluency. However, it is clear that for the most part Yiddish continues to be transmitted to children only within Haredi (Ultra-Orthodox) Ashkenazic Jewish communities, whereas among other sectors of Ashkenazic Jewish society it has largely ceased to function as a vernacular for all but the oldest generations. Outside of the Haredi community, Yiddish can be studied as an academic subject in dozens of universities worldwide, with heritage students and others gaining fluency in the language through such courses as well as through summer schools in various locations. However, the numbers of such individuals are relatively small, and do not constitute a substantial population of intergenerational speakers.

\section{Yiddish music}

In addition to its literary heritage, Yiddish is associated with a long and extremely rich musical tradition dating back to the medieval and early modern periods (see Matut, 2011). 
Yiddish music includes a large repertoire of folksongs (see Rubin, 1979), many of which date back hundreds of years and share characteristics with the music of the East European host nations (Slobin, 2010). Yiddish-speaking culture also has a vibrant tradition of instrumental music, often featuring the clarinet and violin, and traditionally performed at weddings and other special occasions. This instrumental style has become famous in the late 20th and early 21st centuries under the label of 'klezmer', which derives from the Yiddish word for the itinerant musicians who traditionally performed it (Feldman, 2010; Sapoznik, 1999).

In the early 20th century a Yiddish ethnographic movement emerged, whereby Eastern European Jews began to conduct expeditions to collect and document various aspects of Yiddish folk culture, including music and traditional folksongs (see Gottesman, 2003). This period saw the rise of professional Yiddish poets and songwriters whose works were set to music based on these traditional folk melodies. At the same time, new compositions created for the Yiddish theatre and, slightly later, film industry, began to emerge on a large scale. Many of these songs gained huge popularity among Yiddish-speaking Jews in Eastern Europe and among the immigrant communities in North America and elsewhere, and would become established staples of the Yiddish musical repertoire.

In the interwar period, during the peak of Yiddish-language creativity, Yiddish musical styles were not restricted to the traditional folk melodies but also engaged with and adapted the musical traditions of other cultures. For example, tango, which is thought to have emerged in Buenos Aires in the late 1800s and early 1900s based on earlier Latin American dance styles, became popular among Eastern European Jews at this time, and Yiddishlanguage tangos were created in the pre-war and wartime periods, even in the ghettoes and concentration camps (Czackis, 2003). Likewise, swing music was incorporated into the Yiddish repertoires of the pre-war and wartime periods (Wood, 2007b, p. 368; Yiddish Radio Project, 2002). As with Yiddish language and culture more generally, the Holocaust had a sudden and catastrophic effect on the trajectory of Yiddish music (see Wood, 2002). In the post-Holocaust period, the secular Yiddish song repertoire that emerged in the interwar years has typically become taboo in Hasidic communities, being regarded as impure (see Wood, 2007c, p. 209). This is particularly true of the younger generations, in contrast to older Hasidic Jews who grew up in the pre-war period when there was more communication and cultural exchange between Hasidic and non-Hasidic Jewish communities (see Vaisman, 2013, pp. 344-345). Outside of Hasidic circles, Yiddish music has experienced a revival since the 1970s (Wood, 2007b), in tandem with the broader reawakening of interest in Yiddish language and culture mentioned above. 


\section{Postvernacular Yiddish language and music}

While Yiddish has for the most part been lost as a Jewish vernacular outside the Haredi community, the past few decades have seen a growing interest among the descendants of non-Haredi Yiddish speakers in reconnecting with their Eastern European linguistic and cultural roots. One of the main elements driving this rekindled interest is a desire to engage with the music of the Yiddish-speaking world. Thus, on many occasions musicians from diverse backgrounds, both Jewish and non-Jewish, with an interest in performing klezmer music and Yiddish folksongs, may seek to familiarise themselves with the Yiddish language at least to some extent so that they can better understand the songs which they interpret. However, in many cases this engagement with the Yiddish language is largely symbolic in nature: as such, it is common for musicians who perform in Yiddish never to achieve a solid grounding in the language (see Wood, 2007b, p. 374). Thus, within this context, music plays an important role as a potent method of connecting with Yiddish culture and the Yiddishspeaking heritage, which often remains somewhat separate from an actual desire to become a speaker of the language. This phenomenon has been termed 'postvernacularity' by Jewish Studies scholar Jeffrey Shandler (2006). Postvernacularity refers to the life of a language after it has ceased to function as an everyday spoken language. This theoretical framework could be applied to any language which continues to play a role in the life of a cultural group after it is no longer a vernacular - e.g. Greek, Latin, and other ancient languages, as well as endangered and moribund minority languages which continue to possess an important symbolic function after they have largely stopped being spoken by their traditional community (see e.g. Moriarty, 2011).

In the case of Yiddish, as mentioned above, the language is still alive, so postvernacularity does not apply to it across the board in the same way that it does for ancient languages such as Latin or Greek. However, given that in non-Haredi Jewish communities Yiddish has largely ceased to serve as a vernacular and exists primarily as a symbol of Ashkenazic heritage, the concept of postvernacularity is an extremely appropriate lens through which to examine it. In his work on postvernacularity vis-à-vis Yiddish in American Jewish culture (which is largely Ashkenazic), Shandler has noted different realms where the language plays an important cultural role among people who do not speak it fluently, or indeed at all. These include the use of Yiddish in material culture (e.g. coffee mugs, T-shirts, tote bags, fridge magnets, etc.) with single Yiddish words on them like mentsh 'a decent 
human being', oy vey 'oh dear', and yenta 'busybody', and popular Yiddish dictionaries focusing on curses and other words which are often familiar to postvernacular heritage speakers, and which are often regarded as 'funny' or 'cute'. Frequently these have become distilled as representatives of Yiddish culture by people who often think of the language as simply a collection of curses and funny expressions. Further research on postvernacular uses of Yiddish among young American Jews in the 21st century has been conducted by Benor (2013). Her findings include the discovery that the use of Yiddish lexical items has increased among young people in comparison with the previous generation, despite their lack of direct contact with the language (less than $2 \%$ of her survey respondents reported proficiency in the language). The use of Yiddish vocabulary seems to serve as an expression of ethnic identity (Benor, 2013, p. 323), which correlates with the increasing interest and pride in the Yiddishspeaking heritage observed in recent decades mentioned above.

A specific expression of postvernacularity that Shandler (2006, pp. 126-154) has studied is 'Yiddish as performance art', which includes the use of Yiddish in theatre, poetry recitals, Yiddish film screenings, dance, and music. Such events have become popular in recent decades with the increased interest in Yiddish culture mentioned above. In such settings, the postvernacular nature of the Yiddish language is clearly evident: being the vehicle of the music, theatre, and poetry, it has a clearly ritual and symbolic value as the linguistic emblem of Ashkenazic culture, rather than as a communicative medium. At such events, the metalanguage is most typically English (see Wood, 2007a, p. 249), and in many cases most of the audience members and sometimes also the performers have little or no understanding of the Yiddish used in the performances (Wood, 2007b, p. 374).

The hugely important symbolic role of Yiddish in performative settings is summed up by Alicia Svigals, a founding member of the prominent klezmer band The Klezmatics, who observes (cited in Shandler, 2006, pp. 143-144) that klezmer musicians 'are now taking on the same role of serving as a cultural avant-garde that rock musicians have played in the West since the 1960s' [...] 'if there hadn't been a Holocaust, she posits, "there would be Yiddish rock bands today, playing the kind of music we play"'. Central to this statement is the notion that if Yiddish-speaking musical culture in its Eastern European heartland had not been so suddenly and violently devastated in the 1940s, it would have evolved naturally so that in the 21 st century it would encompass the same diverse range of contemporary genres that music in other languages whose trajectories were not cut short have produced. There is an idea that due to the singular historical circumstances which led to the largescale destruction of Yiddish-speaking culture, present-day musicians working with this tradition now have the 
responsibility to commemorate, interpret, and promote pre-war Yiddish music and song in order to keep it alive. This is often manifested in musical performances dedicated explicitly to memorialising and mourning the obliteration of Yiddish culture in the Holocaust (see e.g. Wood, 2002). This drive to commemorate and preserve goes hand in hand with the recognition that the language itself has not evolved in the same way that it might have done in different historical conditions, as the pervasive lack of in-depth knowledge means that new Yiddish-language literary and cultural production is very limited outside of the Haredi world.

Thus, the act of performing in Yiddish is situated firmly within the context of memorialisation and commemoration of what is widely perceived to be a lost world of Yiddish-language musical creativity. This conceptualisation of contemporary Yiddish song performance as a way of honouring and preserving the musical culture that blossomed predominantly in pre-war Eastern Europe is evidenced by the fact that artists most commonly maintain the classic melodies and traditional musical styles of Yiddish folk and theatre songs, with traditional instruments such as the clarinet and violin featuring prominently. As Wood (2007a, p. 248) observes, given the lack of a geographical Yiddishland towards which enthusiasts of Ashkenazic culture can orient themselves, 'a present Yiddish cultural space is created via creative engagement with materials of the Yiddish past'.

\section{Yiddish metal}

Only a few years after Shandler's book on Yiddish postvernacularity was published, the world saw the appearance of the first heavy metal album in Yiddish, and there are currently two bands which perform Yiddish metal music, Gevolt and Dibbukim. The emergence of metal music in Yiddish is a particularly fascinating manifestation of postvernacularity. The choice to produce metal in Yiddish is a striking and perhaps unexpected one because, as Kahn-Harris (2011) has noted, 'Metal is often seen as a quintessentially white, Western, music', and has no overt links with Jewish culture or traditions; in fact, it is often regarded as particularly alien to the Jewish experience. Indeed, associations between metal music and white supremacy (see Kennedy, 2018; King, 2017), including specifically antisemitic ideologies (see e.g. Kahn-Harris 2012), may suggest that the genre is completely incompatible with Jewish language and culture, and that the fusing of the two might be seen as anathema.

Despite such perceptions, the past two decades have seen the emergence of a number of Jewish metal artists, such as the Israeli bands Orphaned Land, Salem, and Arallu, and the 
New York-based Jamie Saft, all of which draw on aspects of Jewish culture in their music (see Kahn-Harris, 2011; Shinefeld, 2011). Notably, Saft's album Black Shabbis is focused specifically around the theme of challenging historical and present-day antisemitism, featuring songs devoted to blood libels, massacres of Jews, and other incidents of anti-Jewish violence (see Kahn-Harris, 2009), and is 'one of the voices out there that stands tall and defiant in the face of much of the anti-Semitism that is promoted by some black and death metal bands' (Jurek, n.d.). However, these bands typically sing in Hebrew or English. Yiddish is not the obvious choice for a contemporary Jewish metal band for two reasons. Firstly, as mentioned above, Yiddish is largely unfamiliar to most of the world's younger generations of Jews, for whom the main two languages are Hebrew (chiefly in Israel) and/or English (particularly in the relatively large Jewish communities of North America, the UK, Australia, and South Africa). Hence, singing in Yiddish would render a band's music comparatively inaccessible, not to mention the fact that most Jewish metal performers are themselves unversed in the language. Secondly, Yiddish has extremely strong connotations with pre-war Eastern European Jewish culture, which (despite the increased interest among younger Jews in recent decades) nevertheless still suffers from relatively widespread perceptions of being outdated and old-fashioned, conjuring images of older relatives and the strictly religious Hasidic community; in short, the very opposite of the sort of subversive culture typically associated with metal music. Hence, the motivation for a metal band to perform in Yiddish could be regarded as extremely low. As such, the fact that two bands have indeed made this choice can be understood as a highly conscious and unexpected decision rather than a practical or incidental one. It might also at first glance seem like a very different phenomenon from the straightforwardly memorialising and commemorative trends seen in the typical examples of Yiddish as performance art discussed above, where the language is generally presented within the context of traditional Ashkenazic musical styles.

However, despite the seeming unlikeliness of the juxtaposition of Yiddish and metal, there are actually some arguments why such a fusion is not only possible but indeed historically apt: as Kahn-Harris (2007) has observed, there are 'some interesting parallels to be drawn between the iconoclasm and radicalism of secular Yiddish culture and the antireligiosity of Metal'. The members of one of the two Yiddish metal bands, Dibbukim, also draw on the established strongly secular connotations of Yiddish culture in response to questions regarding the suitability of the language as the vehicle for their non-traditional music, emphasising in an interview that 'Yiddish is not a religious language' when asked whether traditional Jews would disapprove of their music (devilmetal747, 2011). Hence, the 
active decision that these two bands have made to perform metal in Yiddish despite the practical and cultural reasons not to do so, can thus perhaps be seen as the 21st-century evolution of the pre-war secular Yiddish trend of adopting non-Jewish musical genres such as tango, jazz, and swing, and developing them in a uniquely Jewish way. When regarded in this light, the decision to fuse metal with Yiddish can be seen as an attempt to it pick up from where Svigals' statement left off, going a step further in mediating the relationship between the preservation of pre-war Yiddish culture, Yiddish as a postvernacular cultural symbol, and the evolution of new genres, a reimagining of what would have happened if 20th-century history had treated Yiddish very differently. Moreover, precisely the unlikeliness of the pairing of this 'old-world' language with the rebellious and iconoclastic culture of metal music could be regarded as precisely the sort of subversive juxtaposition to be appreciated by fans of the genre, even if they are unaware of the historical link between Yiddish and secular radicalism. Moreover, the choice to sing metal in a language whose speakers were decimated in the Holocaust can be seen as a conscious response to the antisemitic elements extant in the general metal scene (see below for further discussion of this point). It is relevant to note that this 21st-century attempt to reimagine Yiddish in new musical contexts is not limited to metal; a similar postvernacular phenomenon has been observed in the sampling of old Yiddish songs in contemporary hip-hop music (see Smulyan, 2013; Wood, 2007a).

\section{Gevolt}

Gevolt, who describe themselves as 'Yiddish metal pioneers', are a metal band based in Israel that was founded in 2001 by Anatholy Bonder (vocals), Yevgeny Kushnir (guitars), Oleg Szhumsky (drums), and Max Mann (bass guitar). The founding members were Russian Jews who had immigrated to Israel as teenagers in the 1990s. Gevolt was the world's first band to combine a metal sound with Yiddish lyrics. Bonder says that 'in the beginning it was sort of an absurd joke' to perform metal in Yiddish (Paraszczuk, 2010), pinpointing the commonly held perception mentioned above that the juxtaposition of the old-world sound of Yiddish folk music with the gritty youth culture of heavy metal seems like a bizarre oxymoron. However, they later 'started to see that Yiddish is a bridge between the different generations' (Paraszczuk, 2010).

Gevolt's music can be classed as industrial metal in the Neue Deutsche Härte style, and the band's sound has been compared to that of the German Neue Deutsche Härte band Rammstein (see e.g. Brushvox, 2011; Defiler and Klopstock, 2011; Kahn-Harris, 2011; 
Keum, 2016). However, the line-up also includes a violin, in a nod to traditional Yiddish folk and klezmer style, and the band is sometimes described as metal-folk fusion or metal-klezmer fusion (see e.g. Frank-Backmann, 2012; Naor, 2013); Brushvox (2011) calls it 'an extremely exciting and creative mixture of metal, industrial and classic music elements with folk and traditional roots', while Old Man (2007) suggests that it fits in with the folk metal style established by Scandinavian bands. Their singing is characterised by the deep gravelly voice of Anatholy Bonder, whose sound is often likened to that of Rammstein lead vocalist Till Lindemann (see e.g. Kahn-Harris, 2011; Keum, 2016). On the choice of songs, Bonder notes that 'we chose these old songs because we want to give them a new flavour', adding, that they want 'to make today's youth aware of them' (Paraszczuk, 2010). Thus, their music can be regarded as a way of introducing young metal fans to classic Yiddish songs in a way that appeals directly to their musical tastes. This fits in precisely with the wider aims of the klezmer and Yiddish folk movement's desire to preserve, commemorate, and perpetuate the treasures of Yiddish music for contemporary audiences.

The band's name is based on a common Yiddish expression of horror or annoyance, gevalt, or oy gevalt, meaning something similar to 'oh no' or 'oh, for God's sake', and, as such, evokes direct associations with the Yiddish-speaking Ashkenazic cultural tradition. These associations are obvious even to Ashkenazic Jews who do not actually speak Yiddish, because gevalt, or oy gevalt, is one of a number of expressions that are widely familiar to and commonly used by heritage speakers with little or no knowledge of the language itself. The immediacy of this association can be observed in the title of one of the blogposts reviewing the band, 'Oy! Gevolt Is Anything But' (Frank-Backman, 2012), a play on words relying on readers' familiarity with the expression oy gevalt. Gevolt itself embodies the concept of Yiddish singing as an expression of postvernacularity, in that the band members do not themselves speak the language, though Bonder has learned to read and understand it, and they have a consultant who helps them with the lyrics in their songs (Keum, 2016). Similarly, the band's fan base includes not only Yiddish-speaking enthusiasts but also a wider body of people with an interest in Yiddish song as well as in world metal.

Gevolt's first album, Siddur 'Jewish Prayerbook' (2006) was in Russian, but at the time of its release they had already begun putting their idea of singing metal in Yiddish into practice with a metal version of the classic Yiddish folksong Tum Balalaika (2005). Importantly from the perspective of the postvernacular role of Yiddish as a symbol of the survival of Ashkenazic culture, Gevolt members say (Keum 2016) that the chief factor which cemented their decision to continue singing in Yiddish, and go on to produce an entire album 
in the language, was their subsequent experience interpreting the song Zog nit keynmol 'Never Say'. Zog nit keynmol was the anthem of Jewish partisan groups in Vilna and elsewhere in Eastern Europe during the Holocaust, and remains perhaps the most prominent musical symbol of Jewish resistance to the Nazis (see below for further discussion).

In 2011 Gevolt made history with the production of the world's first full-length Yiddish-language metal album. The album is entitled AlefBase (2011), which is a pun on the Yiddish word alefbeys, meaning 'alphabet', and 'bass'. As with the name of the band itself, the album's title serves to evoke a central element of Ashkenazic society the Hebrew/Yiddish alphabet. The alefbeys occupies a prominent and highly respected position in Jewish culture, symbolically representing the entire Torah and by extension all of Jewish learning. The name is also an intertextual allusion to the famous late 19th-century Yiddish song Oyfn pripetshik 'The Alphabet/On the Hearth', by well-known folk poet and composer Mark Warshawsky (1848-1907), which paints a vivid nostalgic picture of how children used to learn the alefbeys in kheyder, the traditional Eastern European educational establishment for young boys where, starting at the age of three, they would learn to read Hebrew and study the siddur and Torah. Oyfn pripetshik is a classic staple of the modern Yiddish musical repertoire and is often one of the first songs that beginning students of the language learn in classroom contexts: for example, it features early on in one of the most widely used contemporary Yiddish language textbooks (Zucker, 1994). The juxtaposition of this image of the alefbeys with the reference to the bass guitar produces a striking symbol of this fusion of the desire to memorialise the pre-war Yiddish-speaking world of Eastern Europe with the 21st-century associations of metal music.

\section{Dibbukim}

The second metal band which has produced a full album in Yiddish is called Dibbukim. Dibbukim is based in Sweden and was founded in 2009 by a couple, Niklas and Ida Olniansky, both of whom say that Yiddish and metal are their two biggest interests, and that this inspired Ida Olniansky with the idea to combine the two (devilmetal747, 2011). Before founding Dibbukim, Niklas (under the previous surname of Olausson) was a member of the power metal band Broken Dagger (2003-2008) and the Viking metal band Folkearth (2006), and sang for the thrash/doom metal band Veritate between 2009 and 2011.

As in the case of Gevolt, Dibbukim's name reflects the centrality of Yiddish culture to its raison d'etre. A dibbuk (plural dibbukim) is the Yiddish and Hebrew word for a figure of Eastern European Jewish folklore, the spirit of a deceased person who takes over a living 
body in order to express unfinished business (see Scholem, 2007). The prominence of the dibbuk in Ashkenazic tradition is exemplified by the fact that it became the subject of a famous expressionistic four-act Yiddish-language play by the prominent writer and ethnographer S. An-ski, Der dibek: tsvishn tsvey veltn 'The Dybbuk: Between Two Worlds', which premiered in Warsaw in 1920. Der dibek was based on materials collected during Anski's ethnographic expeditions among Russian Jews before World War I (Steinlauf, 2010). The play was made into a film of the same name in Poland in 1937, which would later be regarded as a classic of Yiddish cinema (Hoberman, 2010, pp. 279-285), as well as being adapted into an opera and a ballet, and 'became the accredited emissary of Jewish theater art to the world at large' (Steinlauf, 2010).

Dibbukim call themselves a 'klezmer metal band'. In contrast to Gevolt, which have performed in Russian, Dibbukim's repertoire is exclusively in Yiddish. They describe their sound 'as a mix between a metalized version of the old Klezmer tradition and Nordic Folk Metal in the veins of Tyr and Korpiklaani' (devilmetal747, 2011), and some elements of their musical style have also been compared to Iron Maiden (Angry Metal Guy, 2011). KahnHarris (2011) describes the band as 'a standard metal bass/drums/guitar set up with male and female vocals'. The members of Dibbukim are different from those of Gevolt in that they do speak Yiddish, and are involved in other Yiddish cultural projects: for example, in 2010 they founded a Yiddish-language publishing house, Olniansky Text, which commissions original material, mainly children's books. Indeed, they cite their love of Yiddish and desire to participate in its revitalisation as one of the motivating factors behind their choice to sing in the language, noting that they 'truly want to spread this wonderful mystic language' (devilmetal747, 2011). Moreover, in contrast to Gevolt, some of the songs featured on their full-length album are original compositions. Dibbukim is also different from Gevolt in that it is more closely linked with the traditional klezmer scene: for example, they performed a Yiddish-language cover of The House of the Rising Sun at the Lund Klezmer Festival in Lund, Sweden in 2016. However, Dibbukim resembles Gevolt in that the majority of songs on their album are the same kinds of popular classics that feature on AlefBase.

Dibbukim's first, and to date only, album is called Az a foygl un a goylem tantsn 'When a Bird and a Golem Dance' (2011). Like AlefBase, the title of Dibbukim's album evokes explicit associations with Yiddish culture. It does this via the reference to the golem, a clay man which according to Jewish legend can be brought to life by magical incantations, and which, like the dibbuk, is a popular fixture of Ashkenazic folklore. The most famous example of this legend is the golem of Prague, who in popular Eastern European Jewish 
belief is thought to have been created by Judah Loew (d. 1609), the chief rabbi of Prague, in order to protect the city's Jews from antisemitic attacks (see Kieval, 2010).

\section{The bands' repertoires}

The types of songs chosen for the Yiddish albums of both Gevolt and Dibbukim clearly illustrate the way in which the bands employ the language as a postvernacular symbol with the innovative twist of adapting it to a non-traditional musical genre. The albums consist primarily of familiar and well-loved Yiddish folk and theatre songs, many of which are familiar to large numbers of Ashkenazic Jews, and all of which are staples of the international klezmer and Yiddish music circuits. In some cases, the same traditional song is performed by both bands, a testament to their popularity and perceived indispensability on what can be regarded as a metal version of a Yiddish 'greatest hits' album.

\section{Lullabies and children's songs}

Perhaps surprisingly from a metal perspective, lullabies and other children's songs feature prominently on both AlefBase and Az a foygl un a goylem tantsn. For example, both albums include the folksong A mol iz geven a mayse 'Once upon a Time', a melancholy lullaby about the downfall of a Jewish king and queen. The lyrics allude to the biblical story of the wicked queen Jezebel recounted in 1 Kings 21, and have also been interpreted as a parable about the Jewish people. Like the other songs on the albums, A mol iz geven a mayse has been performed by many eminent Yiddish folk singers, such as Chava Alberstein, an Israeli performer who is well known for her Yiddish repertoire as well as her Hebrew one. The song's chorus includes the refrain lyulinke mayn feygele, lyulinke mayn kind 'sleep, my little bird, sleep, my child', which marks it unambiguously as a lullaby. This refrain, along with the rest of the traditional lyrics and the melody, is retained in the metal versions.

Another celebrated Yiddish lullaby, which appears on Dibbukim's album, is Rozhinkes mit mandlen 'Raisins with Almonds', which was written by Avrom Goldfaden (1840-1908), popularly known as 'the father of Yiddish theatre'. Rozhinkes mit mandlen has been made famous in popular Ashkenazic culture by the Barry Sisters (Minnie and Clara Bagelman), a renowned Yiddish duo who were active in the United States from the 1940s to the 1970s and performed some of the best-known versions of many classic Yiddish songs. Dibbukim's album also includes the lullaby Oyfn veg shteyt a boym 'On the Road Stands a Tree', written by the beloved Yiddish poet and balladeer Itsik Manger (1901-1969), whose 
numerous compositions have become classics (see Gal-Ed, 2016). Oyfn veg shteyt a boym is one of his most famous compositions, and has been performed by various singers including Chava Alberstein. It tells the story of a baby bird who yearns to fly off and leave his tree, but who is weighed down literally and figuratively by his mother's excessive worry for his health when he leaves home.

Gevolt's album also includes the traditional children's song Tshiribim tshiribom, which has been most famously performed by the Barry Sisters, and the classic song Der rebe elimelekh 'Rebbe Elimelech', a Yiddish version of the 18th-century English nursery rhyme Old King Cole composed in 1927 by the prominent Yiddish poet and satirist Moshe Nadir (1885-1943). Der rebe elimelekh has been famously performed by many Yiddish folk singers, including e.g. Theodore Bikel, who is well known for his long-standing role as Tevye in the Broadway musical Fiddler on the Roof.

The fact that lullabies and other children's songs feature so prominently on the two albums, alongside other Yiddish classics, is striking evidence of the bands' desire to honour and commemorate pre-war Ashkenazic musical culture: rather than selecting these songs in order to interrogate or subvert them, they have chosen them because of the centrality of the genre to the traditional Yiddish repertoire, and the fact that these are some of the most wellloved and familiar songs to many Jews of Eastern European heritage. This approach can be contrasted with the use of lullabies by major English-language metal bands: for example, Metallica's Enter Sandman is inspired by a lullaby but is used ironically to invoke the opposite of the calm feelings typically associated with a child's sleep song.

\section{Love songs}

Like lullabies, love songs are a staple of the traditional Yiddish song repertoire, and are as such well represented among the songs on the two Yiddish metal albums. Some of the bestknown Yiddish love songs are traditional folksongs without a known author. One of these is perhaps the most famous Yiddish song, Tum balalaika, whose lyrics consist of a conversation between a boy and a girl, in which he poses her riddles and she deftly solves them. The song has been made famous in performance by numerous Yiddish folk singers, including the Barry Sisters. Tum balalaika appears on both Gevolt's AlefBase and Dibbukim's Az a foygl un a goylem tantsn, which is a testament to its great popularity and familiarity to generations of Ashkenazic Jews, even those without deep knowledge of Yiddish-speaking culture.

Another well-known love song appearing on Gevolt's album is Bay mir bistu sheyn 'You're Beautiful to Me', which was written in 1932 by the Yiddish theatre and vaudeville 
performer, director, and composer Jacob Jacobs (1890-1977) for a New York Yiddishlanguage musical play. Like many of the other songs on both albums, Bay mir bistu sheyn has been immortalised by various established Yiddish folk singers, including the Barry Sisters, and was also made famous among more general audiences in an English version by the (nonJewish) Andrews Sisters recorded in 1937.

\section{Theatre songs}

As mentioned above, Yiddish-language theatre and film occupied a central position in prewar Eastern European Jewish culture, and many of the most famous songs in the traditional Yiddish repertoire were originally composed for the theatre or cinema. One of these is the song Yidl mitn fidl 'Yidl with his Fiddle', which appears on Dibbukim's album. It was written by Itsik Manger for an eponymous film which came out in Poland in 1936. The film starred Molly Picon (1898-1992), a luminary of the Yiddish theatre and cinema in the interwar period who performed mostly in the United States. Yidl mitn fidl is a romantic musical comedy about a father and daughter musical duo who, when evicted from their lodgings, are forced to set out on the road through rural Poland as itinerant performers. Deeming this lifestyle too dangerous for a young girl, they decide that Picon's character should disguise herself as a boy. The song Yidl mitn fidl is cheerful and upbeat in tone, with lyrics describing the pair of klezmer musicians as they journey on a wagon through the Polish countryside, encountering a goat and a bird along the way and commenting on the importance of enjoying life. It is performed to the accompaniment of lively violin music. Made famous by Picon, the song has remained a central element of the Yiddish musical canon. Dibbukim's version retains the fiddle and cheerful tone of the original, but fuses it with fast-paced metal bass and drums.

Dibbukim's album also features the song Papirosn 'Cigarettes', which was composed in the 1920s in Eastern Europe by Yiddish actor, director, and playwright Herman Yablokoff (1903-1981). This heart-breaking song movingly describes the tragic fate of a starving orphan boy forced to eke out a living by selling cigarettes and matches on the street, lamenting the death of his mother and sister from crushing poverty. It was inspired by Yablokoff's own childhood experiences during World War I and by the post-war sight of children hawking cigarettes on the streets of Poland and Lithuania. The song was popularised on American Yiddish radio in 1932 and then even more so when it featured in a Yiddish play of the same name which Yablokoff produced in 1935. Papirosn has since been performed by the Barry Sisters and other famous Yiddish singers. The music is based on a Bulgarian folk tune and it 
is often performed as a doina, a style popular in Ashkenazic Jewish music which derives from a Romanian folk form linked to Middle Eastern musical forms and consists of 'sparse backup chords against which a soloist improvises a weaving, twisting, plaintive melody' (Slobin, 1987, p. 97). However, it can also be performed in a livelier style. Dibbukim's version, like its other renditions of Yiddish folksongs, preserves the traditional melody.

\section{Resistance songs}

One of the songs on Gevolt's AlefBase is the quintessential song of Jewish resistance against the Nazis, entitled Zog nit keynmol 'Never Say', also called Partizaner Lid 'Partisan Song'. Zog nit keynmol was composed in 1943 by the Yiddish poet Hirsh Glick (1922-1944), a Yiddish poet and editor who spent the early 1940s in the Vilna Ghetto and nearby forced labour camps (Schulman \& Miller, 2007) and subsequently died fighting the Nazis in Estonia after escaping from a concentration camp. The song vividly evokes the partisans' struggles in the ghettoes and camps with lines such as dos hot a folk tsvishn falndike vent / dos lid gezungen mit naganes in di hent 'a people between collapsing walls / sang this song with pistols in their hands'. It has been immortalised by a number of established Yiddish singers, including Chava Alberstein and Martha Schlamme, an extremely well-known Austrian-born performer of Yiddish folk songs who was active in the United States from the 1950s to 1980s.

As the band members observe in an interview (Keum, 2016), they were inspired to perform this song in a metal style because it 'touched the members of the band deeply and motivated them further to "make it powerful. Because of this song, the whole album AlefBase came out. With this song, we knew we had to do it."' This is perhaps the most striking example of the two bands' postvernacular drive to preserve and honour Yiddish heritage: it was Zog nit keynmol's powerful emotional associations with Jewish resistance and the cultural world destroyed in the Holocaust which motivated Gevolt's members to commit themselves to singing in their heritage language, even though they were not actually speakers of it, and thus to play a role in its continued existence. In this respect, the band's choice of song can be regarded as the same type of commemoration of the Holocaust and the destruction of Yiddish musical culture often seen in more traditional klezmer performances. It also serves as a direct challenge, like Jamie Saft's Black Shabbis, to the racist and antisemitic elements that exist within metal culture. (Indeed, protest songs are a wellestablished element of metal music more broadly; see Malott and Peña 2004 and Varas-Díaz and Scott 2016). Ironically, a recent review of AlefBase featured on the Bulgarian metal 
webzine Today's Metal-Bulgaria (Zorn, 2011) is itself laden with overtly antisemitic tropes, including comments such as se predlaga bezplatno (evrei - bezplatno, zabelezhete ironijata) '[the album] is available for free (Jews - free, note the irony)' and ne e zad'lzhitelno da xaresvate evreite kato nacija, za da xaresate tozi album 'you do not have to like the Jews as a nation to like this album'. These comments highlight the importance of the very existence of explicitly Jewish bands such as Gevolt and Dibbukim within the metal scene. More broadly, Gevolt's choice to perform Zog nit keynmol can be regarded as part of a global trend whereby minority peoples harness contemporary musical genres as a way of dealing with historical traumas (see Sheffield, 2011 for a discussion of this phenomenon in the case of Native American hip-hop). Kahn-Harris (2011) suggests that Gevolt's selection of Zog nit keynmol may also raise additional questions such as the possibility that Yiddish metal is a 'celebration of Jewish - non-Zionist - hardness' or an 'ironic exploration of Jewish hard masculinity', which adds another layer of complexity to this desire to memorialise pre-war Yiddish culture and to process its loss.

\section{Original compositions}

While the majority of songs on the Yiddish albums by Gevolt and Dibbukim are rooted directly in the traditional Yiddish folk and theatre song repertoire, both bands exhibit a degree of interest in moving away from the purely memorialising role typical of postvernacular Yiddish culture by creating original material in the language. This is most evident in the work of Dibbukim, as Az a foygl un a goylem tantsn includes four original compositions in addition to the five traditional ones (plus two instrumental tracks). The original songs are A mabl fun mashke 'A flood of drink', a song about how drinking can drown your sorrows (which is also a popular theme in metal more broadly, e.g. Alestorm's Whisky Hangover, Korpiklaani's Vodka and Happy Little Boozer); Khaloymes 'Dreams', which contains folkloric elements such as the golem; Der rodmakher 'The Wheelmaker', about how we let earthly things control our lives; and Hinter dem tol 'Behind the Valley', about a shretl, a 'gnome' of Yiddish folklore. Examination of the titles and themes of these songs shows that, like those deriving from the traditional repertoire, they focus on Yiddish culture and folklore. This underscores the fact that the bands' main motivation behind choosing to sing in Yiddish is to commemorate and preserve this culture (in addition to their associations with other types of metal, as in the case of A mabl fun mashke).

While Gevolt's original work is thus far more limited than that of Dibbukim, in 2015 they released an original single, called Khokhotshet 'Guffaw', accompanied by a video with 
futuristic, urban, and space images such as skyscrapers, smartphones, and space stations. The music combines the typical Gevolt industrial metal style with a klezmer background. In contrast to Dibbukim's original lyrics, those featured in Khokhotshet are not explicitly linked to traditional Yiddish folk themes; rather, they are instead quite abstract and seem instead to be more closely tied to the classic metal associations with fantasy, including references to dragons and crowns, with the only clearly Yiddish cultural allusion being a mention of bagels. Gevolt say that they plan to compose more original material, though not exclusively in Yiddish; they also intend to write songs in Hebrew, Russian, and possibly English (Keum, 2016). As Kahn-Harris (2007) has noted, it remains to be seen whether the phenomenon of Yiddish metal creativity develops further, or remains something of 'an interesting curiosity'. As of the time of writing, Gevolt has not produced anything new since Khokhotshet, and Dibbukim have not brought out another album since $A z$ a foygl un a goylem tantsn was released in 2011.

\section{Conclusion}

Yiddish metal music comprises an element of a very particular cultural and sociolinguistic phenomenon, namely the postvernacular use of Yiddish as performance art and symbol of Ashkenazic heritage. Gevolt and Dibbukim take their place alongside the numerous contemporary performers who seek to preserve and interpret pre-war Yiddish musical culture. Their choice of traditional Yiddish songs interpreted in a metal style is based primarily on a desire to honour and perpetuate these classic staples of the Yiddish musical repertoire, rather than as a subversive or critical move. However, these metal bands also play an innovative role that goes beyond the preservation of the traditional Yiddish song repertoire: in addition to doing this, their juxtaposition of well-known Yiddish lyrics and melodies with an identifiably metal style helps to reinterpret Yiddish music for contemporary youth culture. As Shinefeld (2007) comments, 'Gevolt aren't singing nostalgia tunes — they've done nothing less than shaken Yiddish back to life'. In this way, Yiddish metal bands can be regarded as continuing the long-established tradition of innovation within Yiddish musical culture, as evidenced in the pre-war incorporation of genres such as tango and swing into the Yiddish repertoires. In addition, their existence can be seen as a challenge to pervasive antisemitic and neo-Nazi tropes and beliefs that can be observed in the wider metal scene. As such, Yiddish metal goes beyond mere commemoration, instead offering an answer to the impossible question of what Yiddish musical creation might look like in the 21st century if the Holocaust 
had not happened and Yiddish had continued to be the main vernacular of the Ashkenazic Jews.

\section{References}

Angry Metal Guy. (2011, May 2) Dibbukim - Az a foygl un a goylem tantsn review. Angry Metal Guy. Retrieved from https://www.angrymetalguy.com/dibbukim-az-a-foygl-un-agoylem-tantsn-review/ (Accessed 6 January 2020)

Aronberg, K. (2012). Interview: Here's for you "the first Yiddish metal band" GEVOLT! Metalshock Finland. Retrieved from https://metalshockfinland.com/2012/01/20/interviewheres-for-you-the-first-yiddish-metal-band-gevolt/ (Accessed 6 January 2020)

Benor, S. B. (2013). Echoes of Yiddish in the speech of twenty-first-century American Jews. In L. Rabinovitch, S. Goren, \& H. S. Pressman (Eds.), Choosing Yiddish: New frontiers of language and culture (pp. 319-337). Detroit: Wayne State University Press.

Brushvox, A. (2011, July 26). Gevolt - AlefBase. Brushvox. Retrieved from http://brushvox.com/2011/07/gevolt-alefbase-2011/ (Accessed 6 January 2020)

devilmetal747. (2011, May 31). Yiddish and metal come together in a unique union with Dibbukim. Brutalism. Retrieved from http://brutalism.com/content/yiddish-and-metal-cometogether-in-a-unique-union-with-dibbukim (Accessed 6 January 2020)

Czackis, L. (2003). Tangele: The history of the Yiddish tango. Jewish Quarterly, 50, 44-52.

Defiler, Y. and Klopstock, L. (2011, April 10). מחמש יוצאת אחת - Wacken Metal Battle 2011 [From five comes forth one - Wacken Metal Battle 2011]. Metal Magazine. Retrieved from http://metalist.co.il/ArticlePrivate.asp?id=255 (Accessed 6 January 2020)

Dibbukim. (2011). Az a foygl un a goylem tantsn. Grandmaster Music. 
Feldman, W. Z. (2010). Music: Traditional and instrumental music. In YIVO Encyclopedia of Jews in Eastern Europe. Retrieved from http://www.yivoencyclopedia.org/article.aspx/Music/Traditional_and_Instrumental_Music (Accessed 6 January 2020)

Frank-Backman, B. (2012, March 27). Oy! Gevolt is anything but (Yiddish klezmer-metal fusion). Jacob's bones: Returning Israel to its source. Retrieved from https://jacobsbones.wordpress.com/2012/03/27/oy-gevolt-is-anything-but-yiddish-kletzmermetal-fusion/ (Accessed 6 January 2020)

Gal-Ed, E. (2016). Niemandsprache: Itzik Manger - ein europäischer Dichter. Berlin: Jüdischer Verlag im Suhrkamp Verlag.

Gevolt. (2011). AlefBase. Gevolt Productions.

Gottesman, I. (2003). Defining the Yiddish nation: The Yiddish folklorists of Poland. Chicago: Wayne State University Press.

Harshav, B. (1990). The meaning of Yiddish. Berkeley: University of California Press.

Jurek, T. (n.d.). AllMusic review: Jamie Saft - Black Shabbis. AllMusic. Retrieved from https://www.allmusic.com/album/mw0000806367 (Accessed 6 January 2020)

Kahn-Harris, K. (2007, August 15). Yiddish metal madness. Retrieved from http://kkahnharris.typepad.com/weblog/2007/08/yiddish-metal-m.html (Accessed 6 January $\underline{2020)}$

(2009, March 17). Hipster metal for hipster Jews. Jewcy. Retrieved from http://jewcy.com/jewish-arts-and-culture/hipster_metal_hipster_jews (Accessed 6 January 2020)

—. (2011, April 20). Yiddish-speaking Vikings. Souciant. Retrieved from http://souciant.com/2011/04/yiddish-speaking-vikings/ (Accessed 6 January 2020) 
—. (2012). 'You are from Israel and that is enough to hate you forever': Racism, globalization, and play within the global extreme metal scene. In J. Wallach, H. M. Berger, \& P. D. Greene (Eds.), Metal rules the globe: Heavy metal music around the world (pp. 200223). Durham, NC: Duke University Press.

Kennedy, T. (2018). Black metal not black-metal: White privilege in online heavy metal spaces. Media International Australia, 169(1), 94-100.

Keum, Y. (2016, April 19). Interview: Gevolt, Israel's Yiddish Metal Pioneers. Israel and You. Retrieved from http://www.israelandyou.com/interview-gevolt-israels-yiddish-metalpioneer/ (Accessed 6 January 2020)

Kieval, H. J. (2010). Golem legend. In YIVO encyclopedia of Jews in Eastern Europe. Retrieved from http://www.yivoencyclopedia.org/article.aspx/Golem_Legend (Accessed 6 January 2020)

King, E. (2017, September 26). How white supremacists infiltrated metal. Pacific Standard. Retrieved from https://psmag.com/social-justice/how-white-supremacists-infiltrated-metal (Accessed 6 January 2020)

Malott, C., \& Peña, M. (2004). Chapter 3: His-story of selected subversive popular musical Genres. Counterpoints, 223, 41-59.

Matut, D. (2011). Dichtung und Musik im frühneuzeitlichen Aschkenas. 2 vols. Leiden: Brill.

Moriarty, M. (2012). New roles for endangered languages. In P. Austin \& J. Sallabank (Eds.), The Cambridge handbook of endangered languages (pp. 446-458). Cambridge: Cambridge University Press.

Naor, O. (2013, November 5). ריקודי עמטאל: פולקפסט בישראל [Folk metal dancing: Folkfest in $\begin{array}{lllll}\text { Israel]. } & \text { Makor } & \text { Rishon. } & \text { Retrieved }\end{array}$ https://www.makorrishon.co.il/nrg/online/47/ART2/519/671.html?hp=47\&cat=309\&loc=6 (Accessed 6 January 2020) 
Old Man (2007, August 5). Gevolt: Yiddish metal. Darkside. Retrieved from https://www.darkside.ru/album/9803/ (Accessed 6 January 2020)

Paraszczuk, J. (2010, October 8). Yiddish is alive and well in the Hebrew city. The Jerusalem Post. Retrieved from https://www.jpost.com/Magazine/Features/Yiddish-is-alive-and-well-inthe-Hebrew-city (Accessed 6 January 2020)

Rabinovitch, L., Goren, S., \& Pressman, H. S. (Eds.). (2013). Choosing Yiddish: New frontiers of language and culture. Detroit: Wayne State University Press.

Rubin, R. (1979). Voices of a people: The story of Yiddish folksong (2nd ed.). Philadelphia: Jewish Publication Society of America.

Sapoznik, H. (1999). Klezmer! Jewish music from Old World to our world. New York: Schirmer Trade Books.

Scholem, G. (2007). Dibbuk (Dybbuk). In M. Berenbaum \& F. Skolnik (Eds.), Encyclopaedia Judaica (2nd ed.) (Vol. 5) (pp. 643-644). Detroit: Macmillan Reference USA.

Shandler, J. (2006). Adventures in Yiddishland: Postvernacular language and culture. Berkeley and Los Angeles: University of California Press.

Sheffield, C. L. (2011). Native American hip-hop and historical trauma: Surviving and healing trauma on the 'Rez'. Studies in American Indian Literatures, 23(3), 94-110.

Shinefield, M. (2007, September 20). Death metal for a 'dying language'. Forward. Retrieved from https://forward.com/articles/11661/death-metal-for-a-dying-language-00515/ (Accessed 6 January 2020)

(2011, March 9). The secret history of Jewish metal. Forward. Retrieved from https://forward.com/culture/135976/the-secret-history-of-jewish-metal/ (Accessed 6 January 2020) 
Slobin, M. (1987). Fiddler off the roof: Klezmer music as an ethnic musical style. In M. Rischin (Ed.), The Jews of North America (pp. 95-104). Detroit: Wayne State University Press.

- (2010). Music: An overview. In YIVO encyclopedia of Jews in Eastern Europe. http://www.yivoencyclopedia.org/article.aspx/Music/An_Overview\#id0ewkdi (Accessed 6 January 2020)

Smulyan, S. E. (2013). The SoCalled past: Sampling Yiddish in hip-hop. In L. Rabinovitch, S. Goren, \& H. S. Pressman (Eds.), Choosing Yiddish: New frontiers of language and culture (pp. 357-375). Detroit: Wayne State University Press.

Steinlauf, M. C. (2010). Dybbuk, The. In YIVO encyclopedia of Jews in Eastern Europe. Retrieved from http://www.yivoencyclopedia.org/article.aspx/Dybbuk_The (Accessed 6 January 2020)

Vaisman, E. (2013). 'Hold on tightly to tradition': Generational differences in Yiddish song repertoires among contemporary Hasidic women. In L. Rabinovitch, S. Goren, \& H. S. Pressman (Eds.), Choosing Yiddish: New frontiers of language and culture (pp. 339-356). Detroit: Wayne State University Press.

Varas-Díaz, N., \& Scott, N. (2016). Heavy metal music and the communal experience. New York: Lexington Press.

Wood, A. (2002). Commemoration and creativity: Remembering the Holocaust in today's Yiddish song. European Judaism, 35(2), 43-56.

_. (2007a). (De)constructing Yiddishland: Solomon and SoCalled's HipHop-Khasene. Ethnomusicology Forum, 16, 243-270.

(2007b). The multiple voices of American klezmer. Journal of the Society for American Music, 1(3), 367-392. 
—. (2007c). Stepping across the divide: Hasidic music in today's Yiddish canon. Ethnomusicology, 51(2), 205-237.

Yiddish Radio Project. (2002). The rise of Yiddish swing. Retrieved from http://yiddishradioproject.org/exhibits/ymis/ (Accessed 6 January 2020)

Zorn. (2011, February 28). Gevolt - 2011 - Alef Base. Today's Metal - Bulgaria. Retrieved from http://www.todaysmetal.com/2011/02/gevolt-2011-alef-base.html (Accessed 6 January 2020)

Zucker, S. (1994). Yiddish: An introduction to the language, literature and culture (Vol. 1). New York: Workmen's Circle. 